\title{
OUT OF OBSCURITY: ON THE IDENTITY OF ENTOSTHODON PERTENELLUS (BROTH.) KIS (FUNARIACEAE)
}

\author{
Nicholas Wilding ${ }^{1}$, Claudine Ah-PENG \\ \& TERRY A. HEDDERSON
}

\begin{abstract}
The obscure African species Entosthodon pertenellus (Broth.) Kis is discussed and its concept clarified. The distribution of E. pertenellus is extended to include Grande Comore, Malawi and La Réunion. We include brief notes on morphological variation within the species, affinity with other members of the genus, habitat, and how to distinguish it from other Entosthodons from the region. A description of the species is provided and it is illustrated for the first time.
\end{abstract}

Key words: Africa, islands, Entosthodon, Funariaceae, moss

Nicholas Wilding, \& Terry A. Hedderson, Bolus Herbarium, Department of Biological Sciences, University of Cape Town, Private Bag X37701 Rondebosch, South Africa; e-mail: nicholaswilding@gmail.com

Claudine Ah-Peng, Bolus Herbarium, Department of Biological Sciences, University of Cape Town, Private Bag X37701 Rondebosch, South Africa, and UMR PVBMT, Université de La Réunion, Faculté des Sciences, BP 7151, 15 Avenue René Cassin, 97715 Sainte-Clotilde Messag. Cedex 9, France

Entosthodon Schwägr., with ca 36 spp. in the region (Ah-Peng \& Bardat 2005; O’Shea 2006; Wilding \& Hedderson 2011), is the most diverse genus of Funariaceae in sub-Saharan Africa. The most poorly understood of these are the species described from East Africa and the neighbouring Western Indian Ocean islands.

Funaria (subg. Entosthodon) pertenella was described by Brotherus (1913) based on material collected in Tanzania by J. Brunnthaler in 1909. The name was subsequently transferred by Kis (1985) to Entosthodon in line with Fife's (1985) concept of the genus. Until recently, the name had not been applied to any specimen other than the type (Kis 1985). However, our ongoing work on the genus in Africa shows that E. pertenellus (Broth.) Kis is fairly widespread in East Africa and the neighbouring islands, and is evidently common in most of the areas where it occurs. Much of the obscurity surrounding the species originates from ambiguities in Brotherus'description in combination with the unusual elevation at which the type was collected.

\footnotetext{
1 Corresponding author
}

Brotherus described this species (as a Funaria) as having leaf margins erect and a limbidium comprising a single series of cells. Inspection of type material, which does not appear mixed with any other species, lends little credence to his description. The leaves of E. pertenellus, however, are at times fairly concave which may be equatable with Brotherus' 'marginibus erectis', and the marginal cells between the shoulders of the leaf and the apex may form a \pm distinct border in some leaves but this never extends any further down the leaf, and is by no means characteristic of the species. A further peculiarity is the low elevation of the type locality, which according to the original description was somewhere between 1000 and $1100 \mathrm{~m}$. To date, this is still the lowest recorded elevation for the species which is most commonly collected at elevations above $1800 \mathrm{~m}$.

Entosthodon pertenellus is here newly recorded for La Réunion, Malawi, and Grande Comore (Ngazidja) (Figs 1-3). Over its distribution, E. pertenellus exhibits variation largely in the degree to which the marginal cells are differentiated between the apex and shoulder of the leaf. The Malawian material is probably the most extreme 


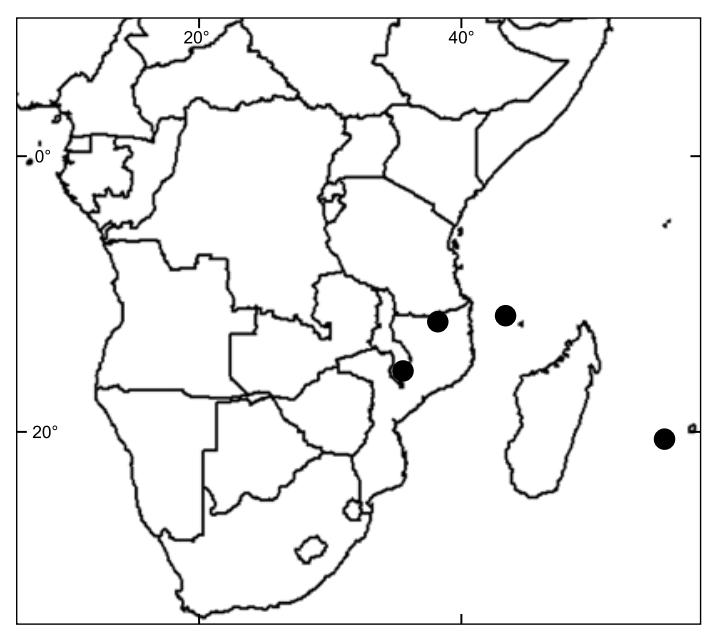

Fig. 1. Distribution of Entosthodon pertenellus (Broth.) Kis. Scale: $1: 89 \mathrm{M}$.

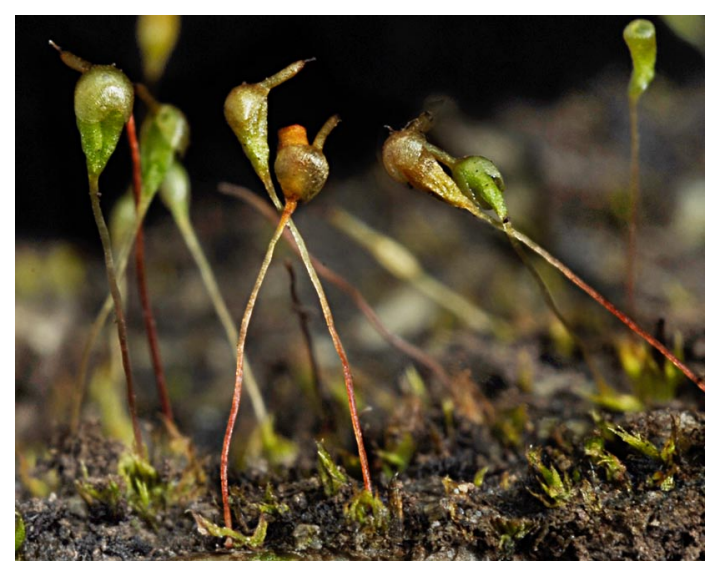

Fig. 2. Entosthodon pertenellus (Broth.) Kis habit. Photograph by J. Bardat.

in this sense and the leaves often have a distinct, sometimes toothed, border between the apex and shoulders of the leaf. Tanzanian and Island (Réunion and Grande Comore) plants are the most similar morphologically while the Malawian plants are in general slightly larger and in addition offer a more or less cohesive set of characters which could justify recognition at a sub-specific level.
Phylogenetic analyses (Wilding et al., unpublished) are, however, unable to resolve the relationship among these major populations suggesting either recent dispersal or some degree of gene flow between populations.

Preliminary phylogenetic analyses (Wilding et al., unpublished) place $E$. pertenellus in the same clade as E. attenuatus (Dicks.) Bryhn, the type species of Entosthodon Schwägr. Morphologically the relationship is apparent as the two share several characteristic features such as oblong-obovate leaves, slightly asymmetric capsules, cerise rhizoids and finely verrucate spores.

In East Africa and the islands, E. pertenellus may be most easily confused with either $E$. jamesonii (Taylor) Mitt. or E. mauritianus Schimp. ex Besch. Entosthodon jamesonii is easily distinguished from E. pertenellus by virtue of its ovate-lanceolate to subulate leaves, with the costa ending below the apex. Entosthodon mauritianus is more similar macroscopically to E. pertenellus, but its conspicuously limbate leaves, with costa ending below the apex clearly place it apart. In La Réunion, the names Funaria perlaxa Thér. and E. rottleri (Schwägr.) Müll. Hal. have been incorrectly applied to material of E. pertenellus. The former two species are recorded for the island based on collections in BOL and REU, all of which have now been identified as E. pertenellus. Funaria perlaxa and E. rottleri should thus be excluded from the Réunion flora.

HABITAT. Entosthodon pertenellus usually occurs on open or exposed soil such as along paths and earthen embankments, and in other areas of moderate disturbance. It is common at elevations between $2300 \mathrm{~m}$ and $2900 \mathrm{~m}$ in Tanzania and $1900 \mathrm{~m}$ and $2600 \mathrm{~m}$ in La Réunion. In Grande Comore and Malawi it is known from elevations around $2000 \mathrm{~m}$.

SELECTED SPECIMENS EXAMINED: MALAWI: Mt. Mulanje, T.A. Hedderson 17420, 17441, 17478, 17491 (BOL). GRANDE COMORE (NGAZIDJA):

Fig. 3. Entosthodon pertenellus (Broth.) Kis: 1 - habit wet; 2 - habit dry; 3 \& 4 - capsules dry; 5 - calyptra; 6-12 - leaves; $13 \& 14$ - leaf apices; 15 - exothecial cells; 16 - cells at capsule mouth. Scale bars: A $(1-5)=1 \mathrm{~mm}, \mathrm{~B}(6-12)=0.5 \mathrm{~mm}$, $\mathrm{C}(13-16)=50 \mu \mathrm{m}, \mathrm{D}(17)=28 \mu \mathrm{m}$. 

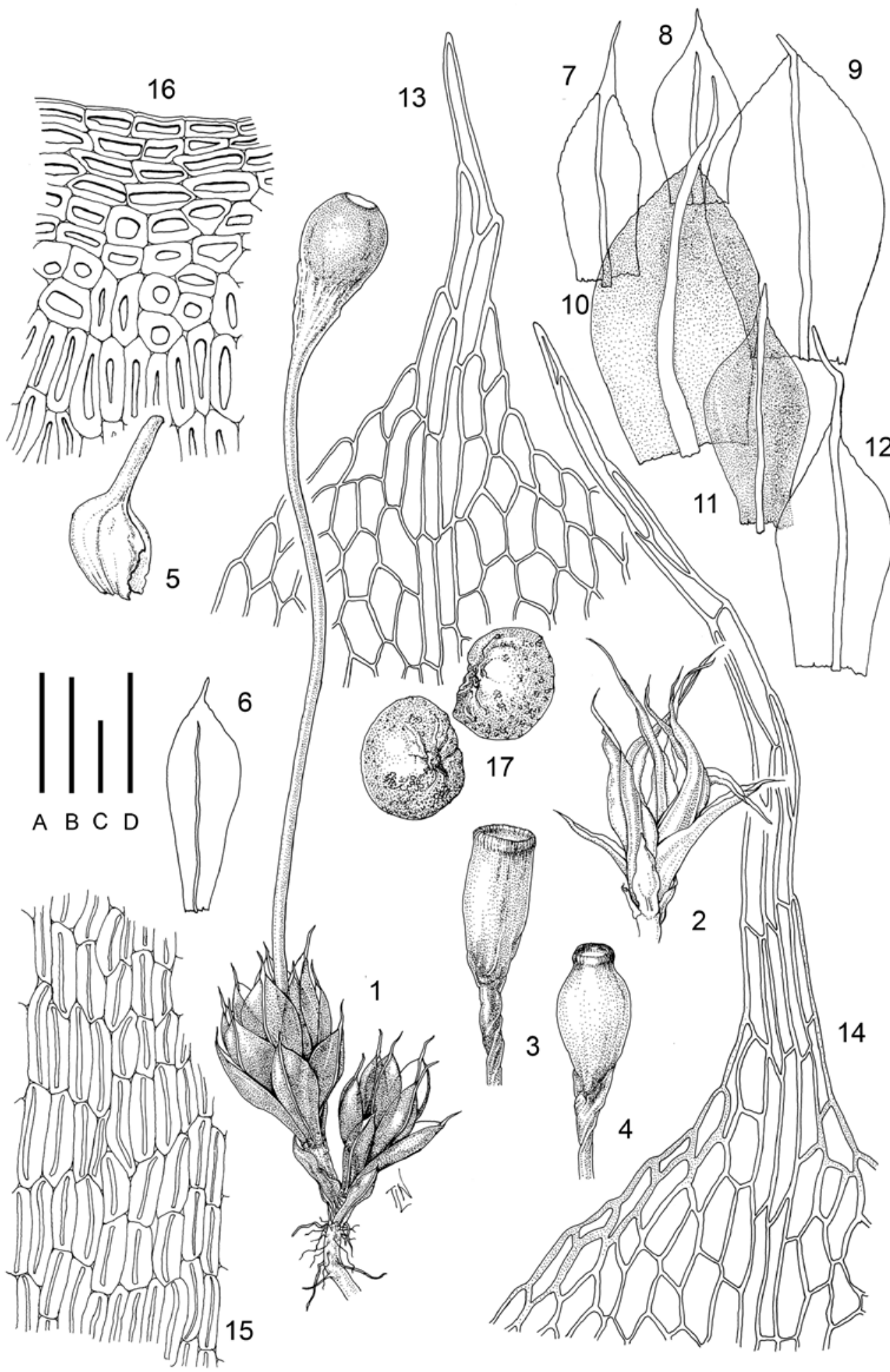
Mt. Kartala, T. Pócs 9159/AL (BOL, EGR). LA RÉUNION: MAFATE, $N$. Wilding 151 (BOL); MAIDO, $N$. Wilding 20, 22b, 22c, 23, 32, 33, 35, 40 (BOL); Ah-Peng \& Hedderson R584-9 (REU); PITON DE LA FournaISE, $N$. Wilding 30, 31, 64, 67, 71, 75, 156, 164 (BOL); Piton des NeIGes, T. A. Hedderson 16634b, 16636, 16637; N. Wilding 166, 167, 185, 237 (BOL); RoCHe ECRITE, N. Wilding 55, 56, 59, 61; T. A. Hedderson 16580 (BOL); TANZANIA: MT. KILIMANJARO, T. Pócs, R. Ochyra \& H. Bednarek-Ochyra $88118 / \mathrm{V}$, $88124 / M, 88125 / W, 88125 / S, T$ (BOL, EGR).

\section{Entosthodon pertenellus (Broth.) Kis}

Figs $2 \& 3$

Funaria pertenella Broth., Denkschr. Kaiserl. Akad. Wiss., Wien. Math.-Naturwiss. K1. 88: 737. 1913. LECTOTYPE (designated here): TANZANIA. West Usambara, Kalange, 1000-1100 m. J. Brunnthaler s.n. (WU!). IsoLECTOTYPE: H!

Plants small, light-green, scattered to gregarious. Stems reddish-brown, 1-3 mm high, branching by sub-perigonial innovation, in cross-section with 1-2 layers of thick-walled reddish-brown cortical cells, a hyalodermis and a central strand, with cerise rhizoids below. Leaves erect-spreading, oblong-obovate, $1.1-1.8 \times 0.4-0.9 \mathrm{~mm}$ (including awn), concave, entire to weakly and bluntly toothed above, short acuminate or rarely apiculate. Cells of upper lamina rectangular to oblong-hexagonal, $(22-) 30-55(-63) \times 12-25(-30) \mu \mathrm{m}$, thinner walled, longer, and more oblong below; marginal cells usually undifferentiated, sometimes forming $\mathrm{a} \pm$ conspicuous border between shoulders and apex; costae reddish brown, usually excurrent, in cross-section with two adaxial and one abaxial layer of large cells surrounding a central stereid group. Axillary hairs present.

Polyoicous. Setae 5-7(-15) mm long, pale yellow to reddish-brown, twisted anti-clockwise. Capsules erect or weakly inclined, slightly asymmetric (from a more or less distinct bend in the neck), narrowly oblong-pyriform, weakly constricted below the mouth when dry, 1.1-1.9 $\times$ 0.4-0.6 mm, with a well differentiated neck $c a$ $1 / 3-1 / 2$ the total length of the capsule, yellowish- to reddish-brown at maturity; mouth transverse, $\mathrm{ca}$ $3 / 4$ the diameter of the capsule; exothecial cells with obscure lumina, ca 40-65 × 8-18 $\mu \mathrm{m}$, in cross-section with thick, strongly cuneate anticlinal walls, ca 4-6 rows of oblate cells at mouth. Opercula planoconvex. Peristome usually absent, if present consisting of a highly reduced and fragmented hyaline membrane. Spores finely verrucate or smooth, $25-33 \mu \mathrm{m}$, trilete scars rarely obvious. Calyptrae cucullate-rostrate.

ACKNOWLEDGEMENTS. This work is part of the MOVECLIM project and was supported by the Agence Nationale de la Recherche, Conseil Régional de la Réunion, Conseil Régional de la Guadeloupe, Government of Azores, Government of Canarias, under the framework of Net-Biome transnational first call. The first author is thankful to the Oppenheimer Memorial Trust and the NRF for supporting his PhD research. We thank Tracey Nowell for the illustrations, and Allan Fife for his valuable comments and suggestions on the manuscript. The authors would like to dedicate this paper to Professor Tamás Pócs for his contribution towards African bryology and his endearingly humble nature as a scientist.

\section{REFERENCES}

AH-PENG C. \& BARDAT J. 2005. Check list of the bryophytes of Réunion Island (France). Trop. Bryol. 26: 89-118.

Brotherus V. F. 1913. Musci. In: J. BrunNthaler, Ergebnisse einer botanischen Forschungsreise nach DeutschOstafrika und Südafrika (Kapland, Natal und Rhodesien). Denkschr. Kaiserl. Akad. Wiss., Wien. Math.-Naturwiss. Kl. 88: 734-743.

FIFE A. J. 1985. A generic revision of the Funariaceae (Bryophyta: Musci). Part 1. J. Hattori Bot. Lab. 58: 149-196.

KIS G. 1985. Mosses of South-East Tropical Africa. An annotated list with distributional data. Institute of Ecology and Botany of the Hungarian Acadamy of Sciences, Vácrátót.

O'SHEA B. J. 2006. Checklist of the mosses of sub-Saharan Africa (version 5, 12/06). Tropical Bryology Research Reports 6: 1-252.

WILDING N. \& HEDDERSON T. A. 2011. Entosthodon jamesonii and $E$. lindigii: two species new for Africa from the Indian Ocean Islands. J. Bryol. 33(4): 326-327. 